\title{
Transfer of Power in Literature and Business: Shakespeare's Measure for Measure and King Lear
}

\author{
Edward R. Raupp
}

\begin{abstract}
The study of Shakespeare's plays, apart from the delight one may experience from the language, plot, and staging, offers useful insights into the enduring problems of human relationships in general and of organizational behavior in particular. Using as text material the tragedy of King Lear and the comedy Measure for Measure, this paper addresses one such organizational problem, succession, the transfer of power from one chief executive to another.
\end{abstract}

Keywords: Lear, Shakespeare, succession, transfer of power

\section{INTRODUCTION}

Much has been published in standard college textbooks, professional journals, and the popular press on the art of using power to manage organizations and enterprises. From Machiavelli (1981/1532) to Drucker (1987), we read advice on how leaders should behave in office in order to gain their objectives. There is, however, a paucity of works advising leaders on the matter of handing over their power to a successor. As a consequence, we have had to make do with the limited resources listed at the end of this paper, with the expectation of adding materials as they become available.

\section{SHAKESPEARE AND BUSINESS}

There are some who might shudder at the thought of mixing the Bard and business, as if literature were somehow demeaned by its juxtaposition to such practical, dull work.

Shakespeare would not think so. Much of his play writing deals with precisely such matters. The Merchant of Venice, for example, is about money, banking, and contract law. Its principal characters, most notably Antonio and Shylock, are practitioners of business. Portia, a "lady richly left," becomes perhaps literature's first female business lawyer.

King Lear deals with wills and estates. And in Measure for Measure, Duke Vincentio gives to Angelo his general power of attorney. Indeed, in one period in the twentieth century, Shakespeare was seen "as above all the practical dramatist" (Stead, 1971, p. 152). As a matter of definition, we should note that the term "business" applies not only to profit-seeking enterprises, but to the full range of organizations, including inter alia, educational and charitable institutions, government agencies, military structures, and volunteer activities of a wide variety.

Manuscript received on March 11, 2021.

Revised Manuscript received on March 15, 2021.

Manuscript published on March 30, 2021.

* Correspondence Author

Edward R. Raupp*, Professor of English Philology and Director, Foreign Language Center, at Gori State Teaching University, Georgia

(C) The Authors. Published by Blue Eyes Intelligence Engineering and Sciences Publication (BEIESP). This is an open access article under the CC BY-NC-ND license (http://creativecommons.org/licenses/by-nc-nd/4.0/)
Many graduates of business schools, with the degree of Master of Business Administration, find employment in such organizations.

\section{POWER}

\section{A. Definitions of Power}

A modern dictionary definition of power, "the ability to do or act," scarcely hints at the complexity of the term as it is used in business organizations and as it is discussed in business college textbooks. (Appleby, 1991, p. 136) defines power as "the ability of individuals (or groups) to induce or influence the beliefs or actions of others," and describes a taxonomy of power developed at the Centre for Creative Leadership (CCL) in Greensboro North Carolina.

The CCL taxonomy sees two broad types of powers: Positional and Personal. The former includes powers vested in a leader by the organization, while the latter includes powers brought to the organization by the leader. For the purposes of this paper, the distinction is most important and can be applied with some effect to both Lear and Vincentio, as we shall see.

\section{B. Positional Powers}

Positional powers in the CCL taxonomies include the following:

Legitimate power depends on the cultural system of rights, obligations, and duties recognized and accepted by the members of the organization as authorized and legitimate. Chief executive officers (CEO) of firms have the greatest degree of legitimate power in their organizations.

Information power acknowledges that leaders often have access to information that the other members do not. Often, the information is of the type that members need in order to do their jobs.

\section{Personal Powers}

Personal powers in the CCL taxonomies include the following:

Expert power is the knowledge and skills that set the leader apart, and for which the leader is respected.

Connection power reflects the social network of which the leader is a member, a network that includes influential people both inside and outside the organization.

Referent power brings people to support leaders who are inspiring, who have charisma, and with whom they want to identify.

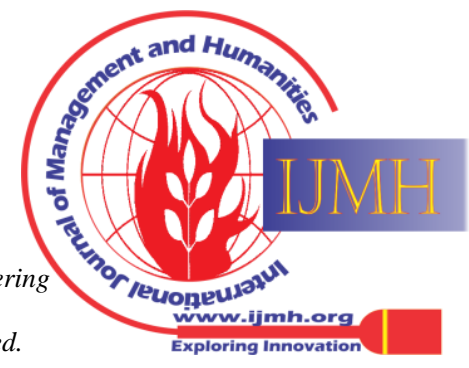




\section{A Comparison of Powers}

The CCL study reported, "Recent research has shown that the most effective managers rely more on the use of personal powers than on positional powers" (Appleby, 1991, p. 137).

We will want to examine the powers of Lear and Vincentio in terms of the CCL taxonomies both before they transferred their powers and after.

For an alternative, perhaps more traditional definition and discussion of power, see Chapter Two, "the Forms of Power: Force, Manipulation, Persuasion," in Wrong (1979, pp. 21-34):

Many writers have defined power as the capacity to impose, penalties or deprivations for non-compliance. Perhaps the most influential of this kind is Max Weber's: In general, we understand by "power" the chance of a man or a number of men to realize their own will in a social action even against the resistance of others who are participating in the action.

Lasswell and Kaplan also reflect this approach: "Power is a special case of the exercise of influence: it is the process of affecting policies of others with the help of (actual or threatened) severe deprivations for non-conformity with the policies intended" (Wrong, 1979, p. 21).

\section{THE TIMING OF POWER TRANSFER}

Before we examine the texts of the two plays for insights into the question of the actual transfer of power, it will be useful to set out some ideas of the events that give rise to the need for a chief executive officer to hand over the charter of leadership to a successor. While there are some overlaps, we will consider these events to be of two kinds: voluntary and involuntary.

The first type of voluntary event is retirement. In recent years, we have seen more and more cases of involuntary retirement, but most instances of retirement arise when the CEO has reached an advanced age and is ready to settle into a more leisurely life. A popular workman's song from the 1587 edition of Holinshead's Chronicles captures the feeling (Patterson, 1989, p. 10):

"My bow is broke, I would unyoke, My foot is sore, I can worke no more."

It is perhaps this kind of event that moves Lear to transfer his power (I.i):

Know that we have divided

In three our kingdom; and 'tis our fast intent

To shake all cares and business from our age, Conferring them on younger strengths, while we Unburthen'd crawl toward death.

Other types of voluntary events giving rise to the transfer of power include resignation (though many CEOs are forced to resign by their boards) and reassignments within the larger organization, such as promotions and transfers.

Involuntary events are many: dismissal (as with Lear's banishment of Kent); demotion; some lateral moves; and certain "grand scale" events involving more than one person, including revolutions, mutinies, and usurpation (as with Richard II by Henry Bolingbroke and both the old Earl of Gloucester and his rightful heir by Edmond in King Lear.)

There remains, of course, the event that gives rise to Vincentio's transfer of power to Angelo, viz., a temporary absence, usually voluntary. as is the case with Vincentio. At the outset, Lear and Vincentio have both positional and personal power. In I.i, Lear gives up virtually all of his positional power (legitimate, reward, coercive, and information) and quickly loses his personal power (expert, connection, and referent) over all but a few loyal people. On the other hand, Vincentio gives his reward and coercive power to Angelo but retains legitimate and (by stealth) information power; the Duke never relinquishes his personal power, which, at the end of the play, has increased substantially.

\section{COMPARISON AND CONTRAST: LEAR AND VINCENTIO}

King Lear and Measure for Measure offer the reader (or, more appropriately, the audience) a rich variety of domains in which to respond to the two plays and to find both similarities and differences regarding their major themes. The same may be said with respect to the issue of power and its transfer from the two chiefs to their designees.

Similarities between the two situations may be seen in the following:

- Both Lear and Vincentio start the plays with great and unchallenged power. They can act in ways that mean life or death, wealth or penury for people in their respective realms, They are both heads of state and of government.

- Both willingly give away their power. At the time of the transfer there is no urgent imperative for either to divest himself of his power.

- Both give their power to undeserving recipients. Goneril and Regan are the very epitome of evil, while Angelo is a hypocrite. All of the recipients are perfectly willing to countenance the killing of innocents (or certainly persons who cannot be said to deserve death) to advance their own ambitions.

- Neither has a wife at the time of the transfer. Lear's queen has apparently predeceased him, and Vincentio appears to be a bachelor.

- Both have servants and subjects who are loyal. Lear has the continued faith of Cordelia, Kent, Albany, and Gloucester, as well as others in his retinue. Vincentio can count on Escalus and the Provost to execute his orders faithfully: "Escalus and the Provost are conscientious and humane. Elbow, the constable, is comically inefficient but not corrupt" (Bawcutt, 1991, p. 25).

- Both Lear and Vincentio have servants and subjects who are disloyal.

Goneril, Regan, Cornwall, and Edmund are treasonous, and Oswald, in being loyal to his mistress is disloyal to the king. Angelo and Lucio are disloyal to Duke Vincentio in their own ways.

Differences between Lear and Vincentio are stark and bear heavily on our question of power and its transfer:

- Age: Lear is "a very foolish fond old man,/ Fourscore and upward, not an hour more or less" (IV.vii. 60-61). Vincentio is a younger man, ready to marry a young maid.

- Location and era: Lear is King of a prehistoric Britain that looks to pagan gods, while Vincentio is Duke of Vienna in the Christian era, when mercy perhaps should be a more highly regarded quality in a leader. Patterson (1989) puts Lear at 844 BCE, 800 years before Macbeth and 800 after Coriolanus (p. 106).

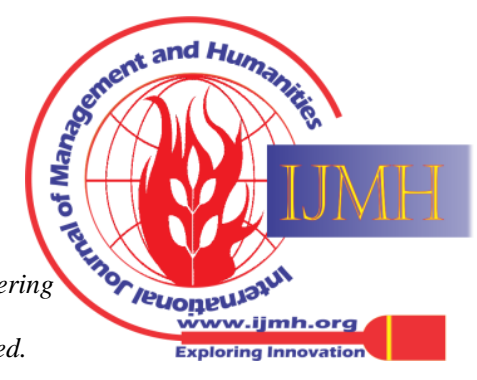


- Flaw: Lear has many flaws, but pride and anger are tragic. He promotes "a land transfer tax to be paid in professions of love" (Patterson, 1989, p. 108). He actively solicits words of flattery to satisfy his vanity (I.i):

"Tell me, my daughters

(since now we will divest us both of rule, Interest of territory cares of state)

Which of you shall we say doth love us most?"

His solicitation is rewarded by deceitful words of praise from Goneril and Regan.

Cordelia's failure to reply in kind brings out of Lear the rage that is his other fatal flaw (I.i.96):

Whether it is better to be loved or feared, or the reverse. The answer is that one would like to be both the one and the other; but because it is difficult to combine them, it is far better to be feared than loved if you cannot be both.

Lear chooses to be loved and loses both love (or, at least, fealty) and fear.

Vincentio, in contrast to Lear, has no apparent flaw. Certainly, none that can be considered fatal is evident in the text. As to flattery and public protestations of love, Vincentio says to Angelo (I.i):

I'll privily away. I love the people.

But do not like to stage me in their eyes:

Though it do well, I do not relish well/Their loud applause and Aves vehement;/Nor do I think the man of safe discretion/That does affect it.

It is precisely the tragic flaws of Lear that lead to disaster, flaws that Vincentio does not possess. Although Lear's Britain has the seeds of civil war, it is his pride and anger that allow the seeds to break open.

\section{A. Intent}

Lear intends to give away his responsibilities but to keep the trappings of his office, including his title and position as King. Any first-year student of management will recognize the inherent contradiction in such an arrangement. Title emoluments, and other perquisites of office should be commensurate with the responsibilities of the job. By giving away the responsibilities of the job but keeping the title, Lear creates a disequilibrium that cannot stand.

Vincentio intends to discover how his deputy will administer a system that has become awkward, as old laws are breached with impunity. Further, he intends to watch over the process and step in when necessary. He yields power and authority for a specific purpose, even though it is not the purpose he shares with Angelo.

\section{B. Duration and Scope}

Lear's gifts to Goneril and Regan are permanent (I.i); to Goneril,

Of all these bounds

We make thee lady; to thine

and Albany's issues

Be this perpetual

And to Regan,

To thee and thine, hereditary ever

Remain this ample third of our fair kingdom.

Vincentio's delegation of power to Angelo, however, is temporary (I.i):

"Hold therefore, Angelo/In our remove, be thou at full ourself."
Note that the scope of power given by both Lear and the Duke is exactly the same, total and complete. Vincentio continues his charge to Angelo: "Your scope is as mine own." So it is clear at the outset in each case as to the duration and scope of the delegation of power.

\section{Identity}

Lear intends to maintain his identity as King, and to his most loyal followers, he succeeds. Among the schemers, however, he loses his identity as King and simply becomes that "very foolish fond old man" of his own description. Of course, given that he has divested himself of his responsibilities, it is difficult to see how he could maintain his identity as King among those who now neither love nor fear him.

Vincentio, by contrast, assumes the identity of a "Friar Lodowick" and instead of leaving for Poland, as he had announced, he stays in Vienna both to observe and, ultimately, control the situation. One might properly question whether a disguise is a morally accepted leadership technique, as all disguises are, per se, a form of dishonesty. In this case, however, it has the effect of sorting out the issues in a just and merciful way. In his article, "The Meaning of Measure for Measure," Clifford Leach says (Stead, 1971, p. 155),

In I.i, the Duke is presumably serious in his profession of trust in Angelo. If he were not, the appointment of Angelo would be inexcusable. Moreover, he professes that Angelo's high character is fully manifest:

"There is a kind of character in thy life,/That to th' observer doth thy history Fully unfold."

Given the demonstrated higher character of Angelo, the Duke adds that such merit should not go unused. In his conversation with Friar Thomas, however, the Duke expresses that degree of doubt that justifies the disguise (I.iii):

Lord Angelo is precise;

Stands at a guard with Envy; scarce confesses That his blood flows; or that his appetite

Is more to bread than stone. Hence shall we see If power change purpose, what our seemers be.

Vincentio, therefore, is practicing an early form of the admonition, "Trust but verify."

In fairness to Angelo, although he has been given notice that the Duke would be checking from time to time, the specific manner of the checking differs from the notice (I.i):

"We shall write to you,/As time and our concerning shall importune,/How it goes with us; and do look to know/ What doth befall you here."

\section{Results}

While all the differences noted here between Lear and Vincentio are important to an understanding of the issue of the transfer of power, none can compare with the differences in the results of the two transactions. Both anticipate a good outcome, but because of the differences in character and situation, the results are nothing alike.
Blue Eyes Intelligence Engineering \& Sciences Publication (C) Copyright: All rights reserved.

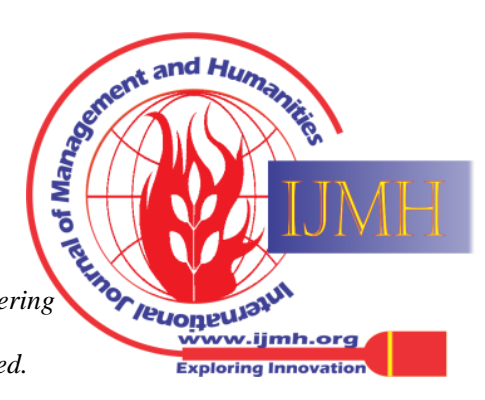


Lear expects a result that will unburden himself from all cares and allow him to rest in Cordelia's sweet nursery between hunting and eating. He further expects to have peace among his presumed heirs. And he expects to retain the dignity and respect owed to a King while ridding himself of all responsibility.

"Yet as soon as the division of the kingdom is completed, the emphasis shifts. Lear learns the contractual relationship between power and responsibility for the powerless, and something about the role of need in establishing economic value" (Patterson, 1989, p. 110.)

This may be one of the few favorable outcomes in King Lear, that a King learns a fundamental lesson about power and responsibility. Lear learns what it is like to be a powerless subject. He also learns the truth of the sonnet (94), "Lilies that fester/Smell worse than weeds." His shock at the treatment he receives from Goneril and her servants is profound (I.iv):

Saddle my horses; call my train together.

Degenerate bastard! I'll not trouble thee:

Yet have I left a daughter.

How sharper than a serpent's tooth it is

To have a thankless child.

But Regan is no more hospitable or respectful to their father than is Goneril. She puts Lear's messenger (Kent in disguise) in degrading stocks. After her greeting of some hope (II.iv), "I am glad to see your Highness." Regan quickly shows her thankless nature, as well: "Oh, Sir! you are old;/Say you have wrong'd her.

Lear is now doubly disappointed in the result of his decisions. Finally, the result of Lear's poorly planned transfer of power is betrayal, war, and death. A King who admits his lapse (III.iv): "I have ta'en/Too little care of this" has lived to see the disastrous consequences of his folly.

As disastrous as the results are for Lear and Britain, the opposite is the case for Vincentio and Vienna. G. Wilson Knight argues that the Duke "is the prophet of an 'enlightened ethic'-that of universal forgiveness and mercy" (Stead, 1971, p. 16). The ethic, hardly visible in Lear (but abundantly clear in Cordelia, Kent, and Edgar), is one that guides Vincentio's decisions throughout the play. And the results, unlike those in King Lear, are most agreeable:

Claudio's life is spared. Juliet will have a loving father for her child. Mariana's long-awaited marriage is accomplished. Angelo's sin is forgiven. Escalus will be rewarded for his goodness. The Provost will be promoted. Isabel will marry the Duke. Vincentio will have a virtuous and faithful bride. Bernardine is pardoned. Mistress Overdone will get a husband. Lucio will receive a just reward.

\section{APPLICATIONS TO MODERN ORGANIZATIONS}

From the epics of Gilgamesh in Sumeria and Homer in Ilium to the Hebrew patriarchal stories to King Lear in prehistoric Britain and Measure for Measure in Renaissance Austria, human character has not changed. We are the same today as were the characters of our mythic past. Therefore, it should not be considered inappropriate to weigh our decisions on the scale of values that have been proven over millennia. That, then, is what we will do in this section, looking at recent cases of chief executives and the transfer of their power to successors. As in King Lear, retirement remains perhaps the single most common reason for handing over the keys to the

senior's office. Yet Peter Drucker (1987) points out that, while most firms continue to act as if the normal retirement age for managers is 65 , the fact is that more and more are taking advantage of early retirement provisions, "some as early as age fifty-two" (p. 144). Organizations today are simply not prepared for this type of power transfer among their leaders. Another signal of the growing importance of retirement is that AARP Magazine, the official publication of the American Association of Retired Persons (AARP), has the largest circulation in the world, with 35 million readers.

Taking another view of the retirement issue, Drucker cites an example of an older executive in an American Bank. At age 63. he headed the bank's Asia-Pacific division and was highly successful in developing the division into a major revenue-producer. "Then 10 years ago, he moved out of operations and became the policymaker, strategist, and adviser on the bank's problem loans to the Third World. Now his associates have persuaded him to stay on a few more years-bur5be no longer travels and no longer negotiates." The secre2,5alccording to Drucker, "as this example shows, is to identify2租e specific strengths of a person and to put them to work" (486147).

The apprazich suggested by Drucker's banker example requires that organizations, and their executives, accept changing roles for individuals based on their skills, interests, and abilities, and not to continue the "up-or-out" policies of the past. Returning to King Lear for a moment, Lear did not have to abdicate in order to have more time for hunting and eating. He needed to redefine his role as King.

This is a matter that cannot be put off for very long. Personnel policies must change in organizations, both profit-seeking and others, to accommodate the growing numbers of new career entrants around the world. Employers will be under heavy pressure from their younger people (Drucker, 1987, p. 148), and organizations will be under similar pressure at the other end of the age spectrum to facilitate succession of top leadership. There are, however, numerous examples of what Jacqueline Graves (1994) calls "Old CEOs Who Can Never Say Goodbye" in her article in Fortune magazine. Graves cites cases of chief executive officers who, after retiring, returned to haunt their successors and forced those successors to resign, causing disruption and conflict: Philip Morris former CEO Hamish Maxwell retained a seat on the board of directors after retiring in 1991. In May of 1994, after the price of the stock fell 13 percent during the year, Maxwell pressured the board to force the resignation of his successor, Michael Miles. ITT's retired CEO Harold Geneen similarly forced the resignation of his successor, Lyman Hamilton. CBS retired CEO William Paley sacked a string of successors before finally settling on Laurence Tisch in 1987. Glaxo Holdings retired CEO Sir Paul Girolami forced the early departure in 1993 of his successor, Dr. Ernest Mario. American Express retired CEO Howard Clark forced the resignation of his successor, James Robinson, in 1993. These sad-but-true examples of CEOs who cannot let go are characterized by Jeffrey Sonnenfeld as "generals" in The Hero's Farewell. "They treasure the recognition they have earned and in leaving high office they leave behind a great deal of their self-worth" (Graves, 1994).

Blue Eyes Intelligence Engineering \& Sciences Publication

(C) Copyright: All rights reserved.

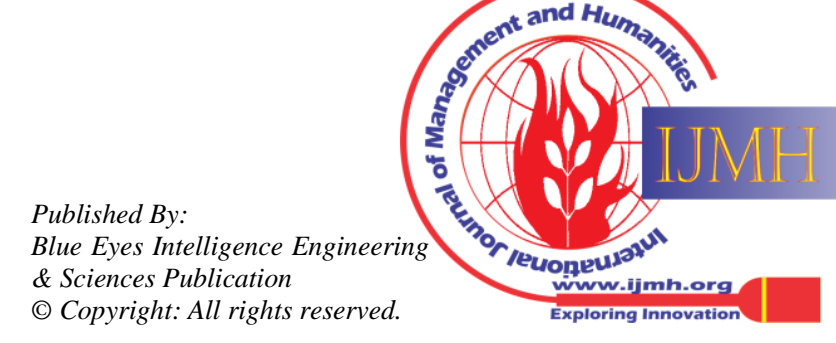


These CEOs, like Lear, want the power that goes with the office from which they retired, but they do not want the "cares and business" of the office. U.S. Shoe retired CEO Philip Barach disagreed with the strategies of his successor for three years after retiring, Instead of forcing the resignation of his successor, Barach himself resigned as chairman of the board, saying, "An old CEO should not be on the board.

I think that he should become an independent consultant, and then the new CEO has no excuses; there are no shadows" (Graves, 1994). Or perhaps the old CEO should travel, grow a garden, teach at a small college in Iowa, or become a Peace Corps Volunteer. In "Burned-Out Bosses," Lee Smith (1994) reaches the pessimistic conclusion that, "Work no longer energizes; it drains (p. 100). In the midst of large-scale corporate downsizing throughout the world, exacerbated by the coronavirus pandemic of 2020, even the "survivors" suffer psychological damage, in some cases worse than those who departed the workplace. Beginning in 1986, Smith reports, and every year since, IBM has been shrinking. "Every year we'd call it something different-early retirement, reorganization, reengineering...It was slow water torture" (p. 103).

\section{CONCLUSION}

Organizations of every kind and place around the world are increasingly being challenged with transitions, as top executives leave one spot for another. Surely, not all the answers will be found in the plays of Shakespeare, but we have seen a glimpse of a way that those works may stimulate the asking of important, relevant, and urgent questions. Lear transferred his power unwisely, with little careful thought, and filled with angry pride, to the wrong people, and the result was catastrophic, both for Lear and all Britain. Vincentio, on the other hand, transferred his power in a planned manner, installed checks, and maintained the ability to control the situation, and the results were most agreeable. Finally, those with or aspiring to power over others may recall Lord Acton's maxim, "Power tends to corrupt, and absolute power corrupts absolutely." Shakespeare, however, shows us that it is often the lust for power that tends to corrupt, as it does with Goneril, Regan, Cornwall, and Edmund. If leaders will consider power as a trust given by members of the organization with the understanding that the leaders will be able to help them, those leaders may be able to avoid the corruption and catastrophes so often evident when power is transferred from one generation of leadership to the next.

\section{REFERENCES}

1. R. C. Appleby, Modern business administration, 5th ed. London: Pitman, 1991.

2. N. W. Bawcutt, The Oxford Shakespeare: Measure for Measure. Oxford: Oxford UP, 1991.

3. S. Clark, The Hutchinson Shakespeare Dictionary, 2nd ed. London: Penguin, 1993.

4. P. F. Drucker, The frontiers of management. Portsmouth, $\mathrm{NH}$ : Heinemann, 1987.

5. D. Farnham, The corporate environment. London: Chartered Institute of Personnel and Development, 1990.

6. J. M. Graves, "Old CEOs who can never say goodbye," Fortune, vol. 130(2), 1994.

7. N. Machiavelli, The prince. Oxford: Oxford World Press, 1981 (Original work published 1532).

8. A. Patterson, Shakespeare and the popular voice. Cambridge, MA: Blackwell. 1989.
9. L. Smith, "Burned-out bosses," Fortune, vol. 130(2). 1994

10. C. K. Stead, Measure for Measure. London: Macmillan.

11. D. Wrong, Power: Its forms, bases, and uses. London: Routledge.

\section{AUTHOR'S PROFILE}

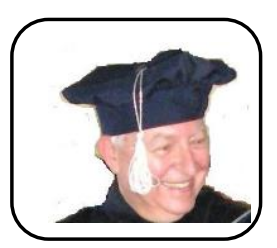

Edward R. Raupp is Professor of English Philology and Director, Foreign Language Center, at Gori State Teaching University, Georgia. He holds Ph.D. degrees in English Language and Literature and in Economics. His research interests are Chaucer, Shakespeare, Milton, and economic development and forecasting. He is Distinguished Professor Emeritus at The University of Georgia

(Tbilisi). He is a full colonel in the United States Army in a retired status.

Details are at:

amazon.com/author/edwardraupp

https://sites.google.com/site/edraupp/

https://gu-ge.academia.edu/EdwardRaupp

ORCID iD QR Code:

https://orcid.org/0000-0001-5147-7835

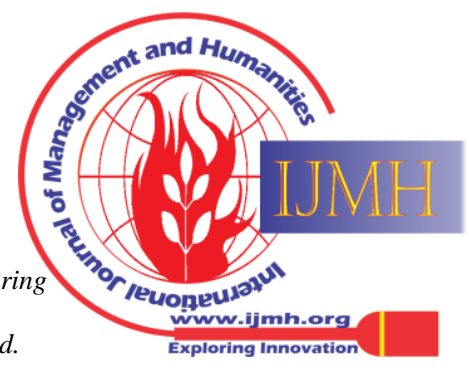

